\title{
Health problems and psychosocial work environment as predictors of long term sickness absence in employees who visited the occupational physician and/or general practitioner in relation to work: a prospective study
}

\author{
H Andrea, A J H M Beurskens, J F M Metsemakers, L G P M van Amelsvoort, \\ $P$ A van den Brandt, C P van Schayck
}

See end of article for authors' affiliations

Correspondence to: Ms $\mathrm{H}$ Andrea, Department of General Practice, Maastricht University, PO Box 616, $6200 \mathrm{MD}$ Maastricht, Netherlands; Helene.Andrea@ HAG.unimaas.nl

Accepted 17 July 2002

\begin{abstract}
Aims: To determine whether psychosocial work environment and indicators of health problems are prospectively related to incident long term sickness absence in employees who visited the occupational physician (OP) and/or general practitioner (GP) in relation to work.

Methods: The baseline measurement (May 1998) of the Maastricht Cohort Study, a prospective cohort study among 45 companies and organisations, was used to select employees at work who indicated having visited the OP and/or GP in relation to work. Self report questionnaires were used to measure indicators of health problems (presence of at least one long term disease, likeliness of having a mental illness, fatigue) and psychosocial work environment (job demands, decision latitude, social support, job satisfaction) as predictors of subsequent sickness absence. Sickness absence data regarding total numbers of sickness absence days were obtained from the companies and occupational health services during an 18 month period (between 1 July 1998 and 31 December 1999). Complete data were available from 1271 employees.

Results: After adjustment for demographics and the other predictors, presence of at least one long term disease (OR 2.36; $95 \% \mathrm{Cl} 1.29$ to 4.29 ) and lower level of decision latitude (OR $1.69 ; 95 \% \mathrm{Cl} 1.22$ to 2.38 ) were the strongest predictors for sickness absence of at least one month. A higher likelihood of having a mental illness, a higher level of fatigue, a lower level of social support at work, and low job satisfaction were also significant predictors for long term sickness absence, but their effect was less strong.

Conclusion: In detecting employees at work but at risk for long term sickness absence, OPs and GPs should take into account not only influence of the psychosocial work environment in general and level of decision latitude in particular, but also influence of indicators of health problems, especially in the form of long term diseases.
\end{abstract}

ong term sickness absence is an economic as well as a medical problem. In the Netherlands, the average absence -rate was, for example, $8.3 \%$ in 1993 , with an estimated cost of $€ 3.9$ billion for the provision of sickness absence benefits alone. ${ }^{1}$ Long term sickness absence has a substantial impact on costs as a result of loss of productivity for the employer. For the employee, it can lead to reduced income or dismissal on grounds of work disability, ${ }^{2}$ and to social isolation, which could lessen the chances of return to work.

Both health problems and work characteristics are reported as predictors of sickness absence. ${ }^{3-7}$ Health problems were found to predict long spells of absence. ${ }^{34}$ Health problems were also associated with employees' negative perception of their psychosocial work environment, ${ }^{89}$ and may therefore mediate relations between employees' perceptions of their psychosocial work environment and sickness absence. ${ }^{10}$ The work environment could also be linked more directly to sickness absence. ${ }^{5}$

In the Netherlands, both the occupational physician (OP) and general practitioner (GP) are often confronted with employees absent because of sickness absence. As a result of their position in Dutch health care, OPs and GPs could play an important role in the prevention of sickness absence. GPs fulfil a function as gatekeeper for both the working and general population, although, unlike their colleagues abroad, they do not certify sickness absence of their own patients. From 1998 on, all Dutch companies have had OPs employed. The tasks of the OP are not only counselling of the employee regarding sickness absence, but also to endorse measures to prevent sickness absence. ${ }^{11}$ As OPs have a good insight in the work environment of employees visiting in relation to work, they can help to shorten sickness absence or to prevent it. OPs advise sick employees and their employers about resuming work and they organise occupational rehabilitation. When they are consulted by employees who are still at work (thus not on sick leave) but experience problems in their work situation, OPs are in a good position to guard the ability of employees to work, by advising both employee and employer how to adjust working conditions of the employee (for example, temporary reduction of number of working hours or a change of job content).

Studying indicators of health problems and psychosocial work environment in employees who visited the OP and/or GP in relation to work may provide the OP and GP with a way to detect patients at risk of long term sickness absence and to identify possible measures to prevent sickness absence in those patients. This group of patients is easily accessible for the OP or the GP, as this group consists of employees who indicated having visited the GP, OP, or both. However, previous

Abbreviations: $\mathrm{Cl}$, confidence interval; GP, general practitioner; OP, occupational physician; OR, odds ratio 
studies regarding predictors of incident long term sickness absence did not focus specifically on this group of employees. The main objective of this study was to determine whether indicators of health problems and psychosocial work environment are prospectively related to company registered long term sickness absence in a working population that visited the OP and/or GP in relation to work. An additional objective was to study whether relations between these predictors and sickness absence were different for employees at work who reported having visited the OP in relation to work and for those reporting having visited the GP in relation to work.

\section{METHODS \\ Study population}

The study population was selected from the Maastricht Cohort Study, a large prospective epidemiological study about fatigue at work in a working population which has been underway in the Netherlands since May 1998. Self report questionnaires were used to collect data on a broad range of work related and non-work related data possibly associated with fatigue among employees from 45 companies and organisations from different sectors, with almost 700 different occupations. ${ }^{12}$ More detailed information about design, procedure, and baseline characteristics of the Maastricht Cohort Study are described elsewhere. ${ }^{13}{ }^{14}$ From the 12140 employees who completed and returned the baseline questionnaire (May 1998), we excluded employees not working at that moment $(n=299)$ or whose sickness absence started before the beginning of our measurement of sickness absence $(n=481)$. Of this remaining working population, 11229 employees (98.8\%) answered the question "Did you visit the OP/GP in relation to your work during the past four months?". In total, 9506 employees $(84.7 \%)$ visited neither GP nor OP, 377 employees $(3.4 \%)$ visited only the OP, 694 employees $(6.2 \%)$ visited only the GP, and 652 employees (5.7\%) visited both the OP and GP. We selected only those employees who reported having visited the OP and/or GP in relation to work $(\mathrm{n}=1723)$, as we wanted to study predictors of sickness absence in a population which was active at work but reported having visited the OP and/or GP in relation to work, as an indicator of experiencing work related problems. When compared to those employees who indicated having visited neither GP nor OP in relation to work, a higher percentage of these employees (30.6\% versus $17.1 \%$ ) reported a low educational level (primary school or lower vocational education), and a higher percentage of these employees $(43.8 \%$ versus $18.6 \%)$ reported the presence of a disease.

\section{Measurements}

Sickness absence data regarding total number of sickness absence days between 1 July 1998 and 31 December 1999 were used, in order to compare employees with sickness absence of a longer duration to employees with no sickness absence/ sickness absence of a short duration. Company offices and occupational health services of the employees involved provided the sickness absence records, for which all cohort participants had given informed consent. Complete sickness absence data were available for 1271 employees, as not all companies and occupational health services were able to deliver complete sickness absence data over the whole 1.5 year period in which the sickness absence records were obtained. To be able to study long term sickness absence, we categorised the sickness absence data in five groups, in which the first category served as the reference group: no/short sickness absence (no sickness absence/sickness absence with a total duration of 1-7 days); sickness absence of 8-29 days; sickness absence of 1-3 months (30-89 days); sickness absence of 3-6 months (90-179 days); and sickness absence of at least 6 months ( 180 days and more). Since sickness absence of up to seven days in one year is usually considered as sickness

\section{The presence of at least one long term disease}

All cohort participants registered in the baseline questionnaire, if they had one or more of the following list of long term conditions:

1. Chronic obstructive pulmonary disease (i.e. asthma or chronic bronchitis)

2. Rhinitis or sinusitis

3. Heart disease or hypertension

4. Stroke

5. Ulcer

6. Chronic intestinal problems

7. Gall bladder problems

8. Cirrhosis or hepatitis

9. Kidney problems

10. Diabetes

11. Thyroid gland problems

12. Chronic back pain

13. Rheumatoid arthritis

14. Epilepsy or multiple sclerosis

15. Migraine or severe headache

16. Chronic skin disease or eczema

17. Cancer

18. Severe consequences of an accident; for example, burns or fractures

absence of a short duration in the Netherlands, our reference group included employees with a maximum of seven absence days in 1.5 years.

To measure the presence of at least one long term disease, employees ticked off whether they had one or more of an extensive list of long term conditions (see box). A Dutch translation of the 12 item version of the General Health Questionnaire (range 12-48, using the Likert score), developed as a screening instrument for detecting minor psychiatric disorders in the general population, ${ }^{15}{ }^{16}$ was used to measure likelihood of having a mental illness. The 20 item Checklist Individual Strength (range 20-140), a multidimensional questionnaire covering aspects of prolonged fatigue during the past two weeks ${ }^{17-19}$ was also included as an indicator of health problems at baseline.

Measurement of psychosocial work environment at baseline consisted of job satisfaction, by means of a single question and of psychosocial work related factors, by means of three subscales of a Dutch version of the Job Content Questionnaire (JCQ). ${ }^{20} 21$ The subscale job demands (five items; range 12-48) relates to demands of the job, time pressure, and conflicting demands. The subscale decision latitude (nine items; range 24-96) assesses the level of skill and creativity required on the job and the flexibility the worker is permitted in deciding what skills to employ, and also the organisationally mediated possibilities for workers to make decisions about their work. Social support (eight items; range 8-32) focuses on supervisors' concern for the welfare of subordinates and co-workers' competence and helpfulness. Job strain, which refers to the combination of high scores on job demands and low scores on decision latitude, has been associated with adverse health effects. ${ }^{20}$ The employees also provided information about demographics: gender, age, and level of education (recoded as low, medium, or high).

\section{Statistical analysis}

All data analyses were performed using SPSS, version 10.0 for Windows. ${ }^{22}$ Employees with incomplete data were excluded from the analyses. Two tailed $t$ tests (for continuous variables) and $\chi^{2}$ tests (for dichotomous/categorical variables) were used to test univariate differences between employees in the reference group (no/short sickness absence) and the other sickness absence groups. The health and work variables (indicators of health problems at baseline and psychosocial work environment at baseline respectively) were included in a multiple 
Table 1 Descriptive baseline characteristics of group no/short sickness absence (employees with no sickness absence/absence of 1-7 days), sickness absence of 8-29 days, sickness absence of 1-3 months (30-89 days), sickness absence of 3-6 months (90-179 days), and sickness absence of at least 6 months (180 days and more) for employees who indicated having visited the OP and/or GP in relation to work during the past 4 months at baseline (total $n=1271$ )

\begin{tabular}{|c|c|c|c|c|c|}
\hline \multirow[b]{2}{*}{ Variable } & \multirow[b]{2}{*}{$\begin{array}{l}\text { No/short sickness } \\
\text { absence }(n=488) \\
\text { Frequency/mean } \\
\text { (SD) }\end{array}$} & \multicolumn{4}{|l|}{ Sickness absence } \\
\hline & & $\begin{array}{l}\text { 8-29 days } \\
\text { (n=326) } \\
\text { Frequency/mean } \\
\text { (SD) }\end{array}$ & $\begin{array}{l}1-3 \text { months } \\
\text { (n=250) } \\
\text { Frequency/mean } \\
\text { (SD) }\end{array}$ & $\begin{array}{l}3-6 \text { months } \\
\text { (n=131) } \\
\text { Frequency/mean } \\
\text { (SD) }\end{array}$ & $\begin{array}{l}\geqslant 6 \text { months } \\
\text { (n=76) } \\
\text { Frequency/mean } \\
\text { (SD) }\end{array}$ \\
\hline \multicolumn{6}{|l|}{ Demographic } \\
\hline Gender: \% male & $76.8 \%$ & $78.5 \%$ & $68.4 \% *$ & $74.8 \%$ & $64.9 \% *$ \\
\hline Age $(y)$ & $41.0(9.6)$ & $40.2(9.0)$ & $40.4(9.3)$ & $40.4(9.9)$ & $42.1(10.1)$ \\
\hline \multicolumn{6}{|l|}{ Highest level of education } \\
\hline Low & $28.2 \%$ & $29.5 \%$ & $33.8 \%$ & $36.0 \%$ & $33.8 \%$ \\
\hline Medium & $46.1 \%$ & $51.4 \%$ & $55.0 \%$ & $52.8 \%$ & $47.9 \%$ \\
\hline High & $25.6 \%$ & $19.0 \%$ & $11.3 \% * * *$ & $11.2 \%$ ** & $18.3 \%$ \\
\hline \multicolumn{6}{|l|}{ Indicators of health problems } \\
\hline $\begin{array}{l}\text { Presence of at least one long term disease } 1 \% \\
\text { yes) }\end{array}$ & $36.5 \%$ & $37.1 \%$ & $47.6 \%$ ** & $55.0 \% * * *$ & $61.8 \% * * *$ \\
\hline $\begin{array}{l}\text { Likeliness of mental illness; GHQ-Likert total } \\
\text { score }\end{array}$ & $26.3(6.7)$ & $26.0(6.4)$ & $26.8(6.9)$ & $26.2(5.9)$ & $28.9(7.4)^{* *}$ \\
\hline Fatigue; CIS total score & $68.5(24.2)$ & $69.7(24.4)$ & $69.2(24.2)$ & 70.5 (23.9) & $82.2(24.0)^{* * *}$ \\
\hline \multicolumn{6}{|l|}{ Psychosocial work environment } \\
\hline \multicolumn{6}{|l|}{ JCQ total score per scale } \\
\hline Job demands & $34.6(6.2)$ & $34.6(5.8)$ & $35.1(6.0)$ & $35.2(6.3)$ & $35.9(6.5)$ \\
\hline Decision latitude & $69.8(12.6)$ & $66.7(12.3)^{* *}$ & $65.6(13.2)^{* * *}$ & $64.5(12.4)^{* * *}$ & $62.7(11.7)^{* * *}$ \\
\hline Social support & $21.8(3.6)$ & $21.4(3.4)$ & $21.2(3.5)^{*}$ & $20.9(3.9)^{*}$ & $20.7(3.7)^{* *}$ \\
\hline Low job satisfaction & $17.0 \%$ & $20.2 \%$ & $25.5 \% * *$ & $27.9 \% * *$ & $32.0 \% * \star$ \\
\hline
\end{tabular}

${ }^{*} \mathrm{p}<0.05$ difference compared to score in group NO/SHORT SICKNESS ABSENCE; * ${ }^{*} \mathrm{p}<0.01$ difference compared to score in group NO/SHORT SICKNESS ABSENCE; ${ }^{* *} p<0.001$ difference compared to score in group NO/SHORT SICKNESS ABSENCE.

$\mathrm{GHQ}=12$ item General Health Questionnaire; CIS = Checklist Individual Strength; JCQ = Job Content Questionnaire.

logistic regression analysis. Multiple regression analyses were only conducted for comparisons between the reference group and sickness absence groups with at least one significant difference on a univariate level regarding the health and work variables. Interaction terms between having visited the OP and/or GP (only the OP, only the GP, or both) and the health and work variables were added to the model to check whether predictors for sickness absence were different for employees having visited only the OP, having visited only the GP, or having visited both. To prevent occurrence of multicollinearity, correlations between all variables were checked beforehand and no high collinearity was found. Furthermore, the continuous predictors were categorised in four groups to check whether a linear relation was appropriate. To ease interpretation from the regression analyses, total scores of continuous variables were standardised by dividing them by their own standard deviation. Demographics were included as control variables.

\section{RESULTS}

Table 1 shows basic characteristics for the study population. We checked at univariate and multivariate levels whether demographic variables, health problems, and psychosocial work environment as predictors of sickness absence were different for employees who visited the OP in relation to work compared to visitors of the GP and visitors of both OP and GP. As we found similar results in all three groups, results are not presented for OP and GP visitors separately. At univariate level, a clear trend was observed, especially for the relation between presence of at least one long term disease and a lower level of decision latitude as predictors for sickness absence of at least one month. To a lesser extent, this trend was also observed for the other health and work variables, except for level of job demands. Regarding number of reported long term diseases, we additionally checked whether a relation was present between reporting one, two, or at least three long term diseases and sickness absence. A moderate positive association was present between number of long term diseases and length of sickness absence (Spearman's rho correlation coefficient, $r=0.17, \mathrm{p}<0.001)$. As indicated in table 1 , the strongest association with respect to the demographic variables was present between a lower educational level and an increasing sickness absence length.

Table 2 presents three multivariate logistic models comparing the reference group with the groups with sickness absence of one to three months, of three to six months, and of at least six months respectively. Three odds ratios are presented for the indicators of health problems and psychosocial work environment: crude odds ratios, odds ratios adjusted for demographics, and odds ratios adjusted for all predictors in the model. Presence of at least one long term disease was the strongest predictor of sickness absence of at least one month. A significant association between level of fatigue and sickness absence of at least six months was found in the model adjusted for demographics, but this association decreased and was no longer significant when adjusted for the other predictors. Scores on the mental illness measure showed no significant association with sickness absence of at least six months, after adjustment for confounding by demographics. With respect to psychosocial work environment, a lower level of decision latitude was the strongest predictor of sickness absence of at least one month. When adjusted for demographics, a higher percentage of employees reporting a low level of job satisfaction were only predictive in the groups with sickness absence of at least three months. Lower level of social support predicted sickness absence of three to six months only moderately. For job satisfaction and social support, the associations disappeared and were no longer significant when adjusted for the other health and work variables. No interactions were found between level of job demands, decision latitude, social support, and subsequent sickness absence. For both indicators of health problems and psychosocial work environment, additional analyses were performed to check whether the reported results were different when also looking at the frequency of sickness absence. These analyses did not reveal considerable differences in the results. 
Table 2 Logistic regression of indicators of health problems and psychosocial work environment on no/short sickness absence (0-7 days; $\mathrm{n}=488$ ) versus sickness absence of $1-3$ months (30-89 days; $n=250), 3-6$ months (90-179 days; $n=131)$, and at least 6 months (180 days and more; $n=76$ ) for employees who indicated having visited the GP and/or $\mathrm{OP}$ in relation to work during the past 4 months at baseline

\begin{tabular}{|c|c|c|c|c|c|c|c|c|c|}
\hline \multirow[b]{2}{*}{ Variable } & \multicolumn{3}{|c|}{$\begin{array}{l}\text { No/short sickness absence versus sickness absence } \\
\text { of } 1-3 \text { months }\end{array}$} & \multicolumn{3}{|c|}{$\begin{array}{l}\text { No/short sickness absence versus sickness absence } \\
\text { of } 3-6 \text { months }\end{array}$} & \multicolumn{3}{|c|}{$\begin{array}{l}\text { No/short sickness absence versus sickness absence } \\
\text { of at least } 6 \text { months }\end{array}$} \\
\hline & $\begin{array}{l}\text { Crude OR } \\
(95 \% \mathrm{Cl})\end{array}$ & $\begin{array}{l}\text { Adj OR } 1 \\
(95 \% \mathrm{Cl})\end{array}$ & $\begin{array}{l}\text { Adj OR } 2 \\
(95 \% \mathrm{Cl})\end{array}$ & $\begin{array}{l}\text { Crude OR } \\
(95 \% \mathrm{Cl})\end{array}$ & $\begin{array}{l}\text { Adj OR } 1 \\
(95 \% \mathrm{Cl})\end{array}$ & $\begin{array}{l}\text { Adj OR } 2 \\
(95 \% \mathrm{Cl})\end{array}$ & $\begin{array}{l}\text { Crude OR } \\
(95 \% \mathrm{Cl})\end{array}$ & $\begin{array}{l}\text { Adj OR } 1 \\
(95 \% \mathrm{Cl})\end{array}$ & $\begin{array}{l}\text { Adj OR } 2 \\
(95 \% \mathrm{Cl})\end{array}$ \\
\hline \multicolumn{10}{|l|}{ Indicators of health problems } \\
\hline Presence at least one long term disease & $\begin{array}{l}1.66^{* *} \\
(1.18 \text { to } 2.32)\end{array}$ & $\begin{array}{l}1.48^{*} \\
(1.04 \text { to } 2.10)\end{array}$ & $\begin{array}{l}1.62 * * \\
(1.13 \text { to } 2.34)\end{array}$ & $\begin{array}{l}2.35^{* * *} \\
(1.53 \text { to } 3.61)\end{array}$ & $\begin{array}{l}2.23^{* * *} \\
(1.43 \text { to } 3.47)\end{array}$ & $\begin{array}{l}2.49 * * * \\
(1.57 \text { to } 3.96)\end{array}$ & $\begin{array}{l}2.77 * * * \\
(1.61 \text { to } 4.77)\end{array}$ & $\begin{array}{l}2.38 * * \\
(1.36 \text { to } 4.17)\end{array}$ & $\begin{array}{l}2.36^{* *} \\
(1.29 \text { to } 4.29)\end{array}$ \\
\hline $\begin{array}{l}\text { Likeliness of mental illness (GHQ-Likert total score per SD } \\
\text { increase) }\end{array}$ & $\begin{array}{l}1.02 \\
(0.99 \text { to } 1.04)\end{array}$ & $\begin{array}{l}1.01 \\
(0.98 \text { to } 1.04)\end{array}$ & $\begin{array}{l}1.00 \\
(0.96 \text { to } 1.03)\end{array}$ & $\begin{array}{l}1.01 \\
(0.98 \text { to } 1.04)\end{array}$ & $\begin{array}{l}1.00 \\
(0.97 \text { to } 1.03)\end{array}$ & $\begin{array}{l}0.97 \\
(0.93 \text { to } 1.02)\end{array}$ & $\begin{array}{l}1.05^{* *} \\
(1.01 \text { to } 1.09)\end{array}$ & 1.04 (1.00 to 1.08$)$ & $\begin{array}{l}0.98 \\
(0.93 \text { to } 1.04)\end{array}$ \\
\hline Fatigue (CIS total score per SD increase) & $\begin{array}{l}1.06 \\
(0.91 \text { to } 1.26)\end{array}$ & $\begin{array}{l}1.04 \\
(0.87 \text { to } 1.24)\end{array}$ & $\begin{array}{l}0.86 \\
(0.69 \text { to } 1.08)\end{array}$ & $\begin{array}{l}1.15 \\
(0.93 \text { to } 1.41)\end{array}$ & $\begin{array}{l}1.15 \\
(0.92 \text { to } 1.43)\end{array}$ & $\begin{array}{l}0.97 \\
(0.71 \text { to } 1.32)\end{array}$ & $\begin{array}{l}1.79 * * * \\
(1.37 \text { to } 2.35)\end{array}$ & $\begin{array}{l}1.75^{* * *} \\
(1.31 \text { to } 2.33)\end{array}$ & $\begin{array}{l}1.48 \\
(0.99 \text { to } 2.21)\end{array}$ \\
\hline \multirow{2}{*}{\multicolumn{10}{|c|}{ Psychosocial work environment }} \\
\hline \multicolumn{7}{|l|}{ JCQ total score per subscale } & & & \\
\hline Job demands (per SD increase) & $\begin{array}{l}1.08 \\
(0.92 \text { to } 1.28)\end{array}$ & $\begin{array}{l}1.06 \\
(0.90 \text { to } 1.26)\end{array}$ & $\begin{array}{l}0.97 \\
(0.81 \text { to } 1.17)\end{array}$ & $\begin{array}{l}1.01 \\
(0.90 \text { to } 1.35)\end{array}$ & $\begin{array}{l}1.09 \\
(0.89 \text { to } 1.35)\end{array}$ & $\begin{array}{l}1.02 \\
(0.81 \text { to } 1.28)\end{array}$ & $\begin{array}{l}1.25 \\
(0.96 \text { to } 1.62)\end{array}$ & $\begin{array}{l}1.19 \\
(0.91 \text { to } 1.55)\end{array}$ & $\begin{array}{l}1.19 \\
(0.90 \text { to } 1.56)\end{array}$ \\
\hline Decision latitude (per SD increase) & $\begin{array}{l}0.69^{* * *} \\
(0.59 \text { to } 0.81)\end{array}$ & $\begin{array}{l}0.76^{* *} \\
(0.64 \text { to } 0.90)\end{array}$ & $\begin{array}{l}0.78^{*} \\
(0.64 \text { to } 0.96)\end{array}$ & $\begin{array}{l}0.64^{* * *} \\
(0.52 \text { to } 0.79)\end{array}$ & $\begin{array}{l}0.67^{* * *} \\
(0.54 \text { to } 0.83)\end{array}$ & $\begin{array}{l}0.72^{*} \\
(0.56 \text { to } 0.93)\end{array}$ & $\begin{array}{l}0.58^{* * *} \\
(0.45 \text { to } 0.74)\end{array}$ & $\begin{array}{l}0.57^{* * *} \\
(0.42 \text { to } 0.75)\end{array}$ & $\begin{array}{l}0.59^{* *} \\
(0.42 \text { to } 0.82)\end{array}$ \\
\hline Social support (per SD increase) & $\begin{array}{l}0.82^{*} \\
(0.70 \text { to } 0.97)\end{array}$ & $\begin{array}{l}0.85 \\
(0.71 \text { to } 1.00)\end{array}$ & $\begin{array}{l}0.9 \\
(0.74 \text { to } 1.11)\end{array}$ & $\begin{array}{l}0.78^{*} \\
(0.63 \text { to } 0.95)\end{array}$ & $\begin{array}{l}0.80^{*} \\
(0.65 \text { to } 0.99)\end{array}$ & $\begin{array}{l}0.92 \\
(0.72 \text { to } 1.18)\end{array}$ & $\begin{array}{l}0.74^{*} \\
(0.57 \text { to } 0.97)\end{array}$ & $\begin{array}{l}0.79 \\
(0.61 \text { to } 1.04)\end{array}$ & $\begin{array}{l}1.06 \\
(0.77 \text { to } 1.46)\end{array}$ \\
\hline Job satisfaction & $\begin{array}{l}0.59 * * \\
(0.40 \text { to } 0.86)\end{array}$ & $\begin{array}{l}0.60^{*} \\
(0.40 \text { to } 0.90)\end{array}$ & $\begin{array}{l}0.73 \\
(0.44 \text { to } 1.20)\end{array}$ & $\begin{array}{l}0.51^{* *} \\
(0.32 \text { to } 0.81)\end{array}$ & $\begin{array}{l}0.49 * * \\
(0.30 \text { to } 0.79)\end{array}$ & $\begin{array}{l}0.59 \\
(0.32 \text { to } 1.08)\end{array}$ & $\begin{array}{l}0.39 * * \\
(0.23 \text { to } 0.69)\end{array}$ & $\begin{array}{l}0.45^{* *} \\
(0.25 \text { to } 0.81)\end{array}$ & $\begin{array}{l}0.77 \\
(0.37 \text { to } 1.61)\end{array}$ \\
\hline
\end{tabular}

${ }^{*} p<0.05$ difference compared to score in group NO/SHORT SICKNESS ABSENCE; * ${ }^{*}<<0.01$ difference compared to score in group NO/SHORT SICKNESS ABSENCE; ** * $p<0.001$ difference compared to score in group NO/SHORT SICKNESS ABSENCE.

Adj OR 1 = odds ratio adjusted for demographics (gender, age, and highest level of education); Adj OR 2 = Adj OR $1+$ adjusted for indicators of health problems and psychosocial work environment; CIS = Checklist Individual Strength; $G H Q=12$ item General Health Questionnaire; $J C Q=$ Job Content Questionnaire. 


\section{DISCUSSION}

We found that in a population of working employees who indicated having visited the OP and/or GP in relation to work in the four months before baseline, the presence of at least one long term disease and a lower level of decision latitude at work predicted sickness absence of at least one month. To our knowledge, this is the first prospective cohort study examining indicators of health problems and psychosocial work environment related to long term sickness absence in a population consisting of employees at work and having visited the OP and/or GP in relation to work. Our identification of the presence of at least one long term disease and level of decision latitude at work as the most relevant predictors of long term sickness absence corresponds with results of the Whitehall II Study (a large prospective cohort study of more than 10000 civil servants with sickness absence as one of the outcomes). Although it should be noted that long term sickness absence was defined as absences of more than seven calendar days ${ }^{3}$ and spells with a length of more than 21 days $^{4}$ in the Whitehall II Study, results of that study also indicated that the longer the duration of sickness absence, the more strongly did the presence of longstanding illness predict rates of absence. Furthermore, jobs with elements of a low level of decision latitude indicated higher rates for long spells of sickness absence. ${ }^{3-5}$ Other studies also identified level of decision latitude as an important predictor. ${ }^{623}$ Also in line with our results, other work related psychosocial factors were found to be less important; social support was only a relevant predictor in male employees, ${ }^{6}$ and job satisfaction was no longer significant after adjustment for self reported health. ${ }^{4}$ Significant longitudinal associations between job strain (the combination of high scores on job demands and low scores on decision latitude) and long spells of sickness absence (at least seven days) were also not found. ${ }^{56}$

Two other studies found contrasting results: high job strain was associated with a higher sickness absence rate, ${ }^{24}$ and the greatest risk of sickness absence was present in employees with a combination of poor levels and negative changes in job control, job demands, and social support. ${ }^{25}$ However, the first study was cross sectional in nature and the second study specifically focused on the change in psychosocial work environment during and after a period of economic decline. Also in contrast to our study, a higher likelihood of having a mental illness (GHQ-30 total score) predicted long spells of sickness absence in the Whitehall II Study. ${ }^{3}$ Our use of the GHQ-12 and adjustment for a broader range of demographic variables, may have contributed to this difference. We have not identified any studies reporting on the relation between fatigue and long term sickness absence. Furthermore, also in line with our results was the finding that measures of health were more strongly associated with rates of longer spells than shorter spells. ${ }^{4}$ From the demographic variables included as control variables in our study, educational level turned out to be a confounder. Taking into consideration the fact that educational level is often viewed as a proxy for measuring socioeconomic status (SES), this finding is in line with the results of studies indicating that meaurements of SES are important factors to take into account in relation to health variables and psychosocial work characteristics ${ }^{26}$ and subsequent sickness

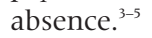

The considerable amount of missing sickness absence data is a point of attention in our study. Not all companies and occupational health services were able to deliver complete sickness absence data for all employees involved in the study. However, as no relation was found between the predictors and the response (availability of sickness absence data in visitors of the OP and/or GP), we expect this bias to be small and nondifferential, and therefore most likely to have only slightly diluted the reported effects. Since assessment of the predictors was based on self report questionnaires, bias may be expected

\section{Main messages}

- In employees at work who visited the OP and/or GP in relation to work, both indicators of health problems and psychosocial work environment were found to predict sickness absence with a duration of at least one month.

- In particular, the presence of at least one long term disease and level of decision latitude predicted long term sickness absence.

\section{Policy implications}

- With regard to employees that visit them in relation to work, OPs and GPs should especially pay attention to the presence of long term diseases and level of decision latitude at work.

at that level as well. However, perception of the employee of his/her health and work situation may be more important than objective assessment in relation to subsequent long term sickness absence, ${ }^{6}$ and self reported psychosocial work environment was found to predict sickness absence as well as more objective measurements. ${ }^{5}$

Sickness absence is a complex phenomenon which is influenced by more factors than health and psychosocial work environment alone. ${ }^{3572728}$ Nevertheless, our study indicates that both indicators of health problems and psychosocial work environment identify employees at risk for long term sickness absence in employees that visited the OP and/or GP in relation to work. Predictors of sickness absence in employees who visited only the OP in relation to work were comparable to predictors in employees who visited only the GP or visited both the GP and/or OP in relation to work. The position of OPs and GPs in the Dutch health system might explain this finding, since they can both be consulted by employees concerning work related problems. While OPs and GPs may both be likely to pay attention to employees' perceptions of their work environment when employees visit in relation to work, results of this study indicate that not only the psychosocial work environment but also the presence of indicators of health problems (especially the presence of at least one long term disease) are important to take into account, regarding detection of employees at risk for long term sickness absence. Future studies are necessary to determine the best role for OPs and GPs in possible interventions for the prevention of long term sickness absence when they are confronted with this population at risk.

\section{ACKNOWLEDGEMENTS}

The Maastricht Cohort Study about Fatigue at Work is part of the Netherlands concerted action on "Fatigue at Work" granted by the Netherlands Organisation for Scientific Research (NWO). The work presented in this paper was and is currently supported by the Netherlands Organisation for Scientific Research (NWO grant no. 580$02.255)$.

\section{Authors' affiliations}

H Andrea, J F M Metsemakers, C P van Schayck, Department of General Practice, Maastricht University, Netherlands

A J H M Beurskens, L G P M van Amelsvoort, P A van den Brandt, Department of Epidemiology, Maastricht University, Netherlands

\section{REFERENCES}

1 Grundemann RWM, Vuuren CV. Preventing absenteeism at the workplace: a European portfolio of case studies. Luxembourg: European Foundation for the Improvement of Living and Working Conditions, Office for Official Publications of the European Communities, 1988.

2 Davidson MJF. ABC of work related disorders. Legal aspects. BM 1996;313:1136-40. 
3 North F, Syme SL, Feeney A, et al. Explaining socioeconomic differences in sickness absence: the Whitehall II Study. BMU 1993;306:361-6.

4 Marmot M, Feeney A, Shipley M, et al. Sickness absence as a measure of health status and functioning: from the UK Whitehall II Study. J Epidemiol Community Health 1995:49:124-30.

5 North FM, Syme SL, Feeney A, et al. Psychosocial work environment and sickness absence among British civil servants: the Whitehall II study. Am J Public Health 1996;86:332-40.

6 Niedhammer I, Bugel I, Goldberg M, et al. Psychosocial factors at work and sickness absence in the Gazel cohort: a prospective study. Occup Environ Med 1998:55:735-41.

7 Voss M, Floderus B, Diderichsen F. Physical, psychosocial, and organisational factors relative to sickness absence: a study based on Sweden Post. Occup Environ Med 2001;58:178-84.

8 Muntaner C, Schoenbach C. Psychosocial work environment and health in U.S. metropolitan areas: a test of the demand-control and demand-control-support models. Int J Health Serv 1994;24:337-53.

9 Stansfeld SA, Fuhrer R, Head J, et al. Work and psychiatric disorder in the Whitehall II Study. J Psychosom Res 1997;43:73-81.

10 Karasek R, Theorell, T. Healthy work: stress, productivity and the reconstruction of working life. New York: Basic Books, 1990

11 Dijk FJH van, Prins R. Occupational health care and work incapacitiy: recent developments in the Netherlands. Occup Med 1995;45:159-66.

12 Bültmann U, Kant IJ, Van Amelsvoort LGPM, et al. Differences in fatigue and psychological distress across occupations: results from the Maastricht Cohort Study of Fatigue at Work. J Occup Environ Med 2001;43:976-83.

13 Kant IJ, Beurksens AJHM, Schroër CAP, et al. De Maastrichtse Cohor Studie naar langdurige psychische vermoeidheid in de arbeidssituatie. [Maastricht Cohort Study about prolonged fatigue at work]. Tiidschrift voor bedriifs- en verzekeringsgeneeskunde 2000;8:226-32.

14 Bültmann U, Kant IJ, Kasl SV, et al. Fatigue and psychological distress in the working population: psychometrics, prevalence and correlates. J Psychosom Res 2002:52:445-52.

15 Goldberg DP, Williams P. A user's guide to the General Health Questionnaire. Windsor: NFER-Nelson, 1988.
16 Koeter MWJ, Ormel J. General Health Questionnaire, Handleiding Nederlandse bewerking [General Health Questionnaire, Manual Dutch version]. Lisse: Swets \& Zeitlinger, 1991.

17 Vercoulen JH, Swanink CM, Fennis JF, et al. Dimensional assessment of chronic fatigue syndrome. J Psychosom Res 1994;38:383-92.

18 Beurskens AJHM, Bültmann U, Kant I, et al. Fatigue among working people: validity of a questionnaire measure. Occup Environ Med 2000;57:353-7.

19 Bültmann U, De Vries M, Beurskens AJHM, et al. Measurement of prolonged fatigue in the working population: determination of a cut-off point for the Checklist Individual Strength. J Occup Health Psychol 2000;5:411-16.

20 Karasek RA. Job Content Questionnaire and user's guide. Los Angeles, CA: University of Southern California, Department of Industrial and Systems Engineering, 1985.

21 Houtman I. Reliability and validity of the Dutch version of the Karasek Job Content Questionnaire. APA/NIOSH Conference on Work, Stress \& Health. Washington, DC: APA, 1995

22 SPSS. SPSS for Windows, version 10.0.5. Chicago: SPSS Inc., 1999

23 Smulders PGW, Nijhuis FJN. The job demands-job control model and absence behaviour: results of a 3-year longitudinal study. Work and Stress 1999;13:115-31.

24 Kristensen TS. Sickness absence and work strain among Danish slaughterhouse workers: an analysis of absence from work regarded as coping behaviour. Soc Sci Med 1991;32:15-27.

25 Vahtera J, Kivimäki M, Pennti J, et al. Effect of change in the psychosocial work environment on sickness absence: a seven year follow up of initially healthy employees. J Epidemiol Community Health 2000;54:484-93.

26 Marmot MG, Smith GD, Stansfeld S, et al. Health inequalities among British civil servants: the Whitehall II study. Lancet 1991;337:1387-93.

27 Briner RB. ABC of work related disorders: absence from work. BM 1996:313:874-7.

28 Whitaker S. The management of sickness absence. Occup Environ Med $2001 ; 58: 420-4$

\section{$\mathrm{ECHO}$}

\section{Electrocution still leads in deaths at work}

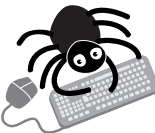

Please visit the Occupational and

Environmental Medicine website [www.occenvmed. com] for link to this full article.
The most comprehensive study ever conducted in the United States has shown that elec-

trocution continues to be a major cause of death among workers because they and their

employers do not recognise the importance of safety training and implementing safe practices.

The findings were based on data spanning 1992-9 collected by the Bureau of Labor Statistics Census of Fatal Occupational Injury (CFOI). They showed the need for much more vigilance in ensuring that regulations on safety training and safe practice are followed. This applied particularly to small firms and young employees. These latest findings also spelt out safety practices for work on or around power cables, especially when operating vehicles or machinery with booms.

As in previous studies with other national datasets most deaths (99\%; 0.43/100 000 /year) occurred in young men (aged 24-30), mainly in white, American Indian, and black men. They peaked in summer, in firms of $\leqslant 10$ workers, and in southern states-a new observation.

Fatal electrocutions by trade were highest in construction (2.10/100 000/year); mining (2.38/100 000 /year); and farming forestry, and fishing (1.16/100 000/year) industries. Within construction electricians came off worst - those installing or repairing power supplies (15.9/ 100000 /year) and their supervisors (7.78/100 000 /year); apprentices (8.25/100 000 /year); and qualified electricians 6.11/100 000 /year). Drilling workers were also at risk-in fact all had been killed by contact with overhead power cables. In agriculture deaths were highest among supervisors of farm workers (3.41/100 000/year).

The CFOI, unlike other occupational databases, covers all trades and compiles its statistics from many diverse sources.

A Injury Prevention 2002;8:306-312. 